RESENHA 



\section{TÁCITO. Diálogo dos oradores. Tradução de Antônio Martinez de Rezende e Júlia Batista Castilho de Avellar. Belo Horizonte: Autêntica, 2014, 144 p. (ISBN: 978-85-8217-318-3).}

Jaqueline Vansan

Universidade Estadual Paulista "Júlio de Mesquita Filho"

Araraquara, São Paulo / Brasil

jaque.vansan@yahoo.com.br

Recebido em 28 de julho de 2016. Aprovado em 23 de setembro de 2016.

Escrito no primeiro século de nossa era, a obra intitulada Diálogo dos oradores (Dialogus de oratoribus), de autoria do proeminente historiador e orador romano Tácito, ganha tradução integral para a língua portuguesa, realizada pelo professor de latim da Universidade Federal de Minas Gerais, Antônio Martinez de Rezende, e pela pesquisadora vinculada à mesma instituição, Júlia Batista Castilho de Avellar, publicada em edição bilíngue pela Editora Autêntica. Esse foi o segundo livro publicado da Coleção Clássica, a qual tem por objetivo oferecer novas versões de textos em prosa ou verso, cujo elevado padrão da escrita e a importância do conteúdo os tornam referência para determinada época ou assunto.

Conhecido principalmente por seu papel como historiador, por meio de obras como Anais (Annales), nos quais retrata a História do Império Romano a partir da morte de Augusto até a morte de Nero, e Histórias (Historiae), em que discorre sobre a época entre a morte de Nero e a de Domiciano, Cornélio Tácito (Cornelius Tacitus) também 
foi autor da biografia de seu sogro Júlio Agrícola (De uita et moribus Iulii Agricolae), ilustre general romano responsável por conquistas na Britânia, e do opúsculo Germânia (De origine et situ Germanorum), no qual descreve a geografia e etnografia do vasto território que fazia fronteira com os domínios dos latinos.

Dentre essas obras taciteanas, portanto, figura o Diálogo dos oradores, texto que oferece uma análise crítica do sistema oratório romano da época do autor. Com datação incerta, acredita-se que a composição veio a público no ano de 102 d.C. e, como o próprio título indica, vale-se do formato do diálogo, fórmula singularizada por Platão e empregada por Aristóteles e Cícero para a veiculação de ideias. Seguindo, então, esse gênero, seu autor simula uma conversa entre Materno, Áper, Secundo e Messala, importantes oradores contemporâneos de Tácito, para discutir questões sobre a formação do orador, sobre a oratória, a poesia e o embate entre esses gêneros, refletindo, ainda, o momento político em que foi composto.

A edição da Editora Autêntica, a saber, além de oferecer a versão em latim e português dessa importante obra, ainda conta com prefácio, texto de apresentação e notas que ajudam na contextualização e no entendimento do conteúdo do diálogo escrito por Tácito. O material é, portanto, "democrático": ao mesmo tempo em que se mostra útil e tornase referência para o estudante e pesquisador de História ou de língua e literatura Clássica, também pode ser apreciado pelo leitor comum, curioso em conhecer a cultura e o pensamento dos tempos antigos.

O prefácio, de responsabilidade de Fábio Duarte Joly, professor de História antiga da Universidade Federal de Ouro Preto, é um convite à leitura do conjunto da obra taciteana. Vinculando a carreira política de Tácito, que chegou a exercer cargos de questor, pretor, cônsul e procônsul da Ásia, com a bibliografia construída pelo autor latino, Joly destaca a unidade de sentido que os escritos, díspares em relação ao gênero, formam. Assim, fornecendo um pequeno panorama de cada uma das obras e relacionando-as com a época em que Tácito as escreveu, isto é, entre o principado de Trajano (98-117 d.C.) e os anos iniciais do reinado de Adriano, o estudioso mostra como a articulação entre a biografia de Agrícola e o livro sobre a Germânia se presta a louvar o imperador Trajano e o novo principado, como os Anais e as Histórias intentam apresentar exemplos de comportamentos aristocráticos favoráveis à consolidação e expansão do Império e à atuação política do senado nesse cenário e dá 
destaque ao modo como o Diálogo dos oradores, discutindo questões oratórias e a adequação da disciplina ao regime vigente, também reverbera os "dilemas e angústias da aristocracia imperial diante das transformações políticas em Roma a partir da segunda metade do século I e ao longo do século II d.C." (JOLY, 2014, p. 12). O texto de Joly, portanto, mais do que explicar e contextualizar a bibliografia taciteana, ainda contribui para lembrar ao leitor dois aspectos importantes em uma obra literária: a indissociabilidade entre o escrito e os ideais, as concepções e anseios que perpassam uma sociedade em determinada época, e, consequentemente, a inexistência de neutralidade em qualquer tipo de discurso, desde o relato sobre a vida de uma pessoa até um texto em que se discutem aspectos da literatura.

A apresentação do Diálogo dos oradores, por seu turno, redigida por Antônio Martinez de Rezende, alerta para importantes aspectos dessa obra, como o seu caráter lacunar, as incertezas quanto à datação e, no passado, à autoria do "tratado", enfatizando, porém, as possibilidades investigativas e de interpretação que tais características estimulam no leitor ou estudioso desse texto antigo. Oferece, além disso, um panorama das características, conteúdo e das questões levantadas no texto, comentando, principalmente, o embate fundamental que sustenta o diálogo: a oposição entre Áper, defensor da "eloquência viril e oratória" $(\mathrm{V}, 3)$ e Materno, o qual sugere, para os novos tempos do império, um novo modelo de oratória, calcado na "eloquência poética" (XII, 2). A inclusão dessa introdução tem o mérito de tornar a edição da Editora Autêntica acessível a todos os tipos de público, uma vez que se propõe tanto como guia daquilo que o Diálogo dos oradores discute, quanto como estímulo à reflexão sobre o que está nas entrelinhas da conversa ficcional imaginada por Tácito.

Também contribuem para a facilitação da leitura e compreensão do texto as abundantes e cuidadosas notas à tradução (117 no total), que identificam as inúmeras personalidades e outros dados de cultura antiga, citados pelos oradores que participam do colóquio sobre o desenvolvimento da arte de construir discursos no período imperial.

A tradução, por sua vez, resulta em um texto fluído e de fácil entendimento, sem que haja, porém, modificação naquilo que se refere ao conteúdo originalmente expresso no texto latino, nem quanto ao estilo empregado na "conversa" que Tácito imagina ocorrer entre renomados oradores da época. Tais traços se observam no trecho a seguir, uma fala 
de Áper, elogiando seus companheiros no diálogo, como cultores dos melhores gêneros de eloquência desenvolvidos naquela época:

Vos uero, [uiri] disertissimi, ut potestis, ut facitis, inlustrate saeculum nostrum pulcherrimo genere dicendi. Nam et te, Messalla, uideo laetissima quaeque antiquorum imitantem, et uos, Materne ac Secunde, ita grauitati sensuum nitorem et cultum uerborum miscetis, ea electio inuentionis, is ordo rerum, ea, quotiens causa poscit, ubertas, ea, quotiens permittit, breuitas, is compositionis decor, ea sententiarum planitas est, sic exprimitis adfectus, sic libertatem temperatis, ut etiam si nostra iudicia malignitas et inuidia tardauerit, uerum de uobis dicturi sint posteri nostri. (TÁCITO, Diálogo dos oradores, XXIII, 5)

Em verdade, vós, ó homens os mais eloquentes, da forma como sois capazes e costumais fazer, ilustrai o nosso século com o mais belo gênero de eloquência. Com efeito, vejo-te, Messala, imitador do que há de mais produtivo nos antigos; quanto a vós Materno e Segundo, de tal modo misturais à seriedade o brilho dos sentidos e ornamento das palavras; tais são os critérios da invenção, tal ordenação das ideias, tal a fecundidade - todas as vezes que a causa exige -, tal a brevidade - todas as vezes que permite -, tal o decoro da composição, tal a simplicidade das sentenças, de tal modo exprimis as disposições de espírito e moderais a liberdade, que, mesmo que a maldade e a inveja nos tenham retardado os juízos, os nossos pósteros hão de dizer a verdade sobre vós. (p. 73)

Vê-se, portanto, nessa passagem, que a tradução de Rezende e Avellar segue fielmente o escrito latino, sem o acréscimo ou supressão de sentenças, no texto de chegada, do texto de partida. A literalidade se verifica com a transposição ao português de "palavra por palavra" do conteúdo do texto em latim. Fato facilmente percebido, por exemplo, 
pela manutenção da repetição do pronome $e a$, do texto latino, por "tal" na tradução portuguesa. Além da fidelidade ao texto, a tradução também revela a preocupação em conservar um pouco do sabor da fala dos rétores antigos, ao optar, por exemplo, pela preservação do tratamento em segunda pessoa do plural, ainda que prefira desfazer o hipérbato que encerra o discurso de Âper, no intuito de preservar a fluência do texto: "Que mesmo que a maldade e a inveja nos tenham retardado os juízos, os nossos pósteros hão de dizer a verdade sobre vós".

A edição do Diálogo dos oradores publicada pela Editora Autêntica, na tradução de Antônio Martinez de Rezende e Júlia Batista Castilho de Avellar, com introdução de Fábio Duarte Joly, por conseguinte, tanto torna acessível a obra de Tácito ao grande público, como contribui com as demais referências que podem ser consultadas pelos estudantes de língua, literatura e História da Roma Clássica. O livro e toda a Coleção Clássica organizada por Oséias Silas Ferraz para a Editora de Belo Horizonte também se destacam por ser fruto do trabalho conjunto e cuidadoso de especialistas brasileiros no tema. 